\title{
Antibacterial and antifungal potentials of the solvents extracts from Eryngium caeruleum, Notholirion thomsonianum and Allium consanguineum
}

Abdul Sadiq ${ }^{1 *}$, Sadiq Ahmad ${ }^{1}$, Rahmat Ali ${ }^{1}$, Fawad Ahmad', Sajjad Ahmad ${ }^{1}$, Anwar Zeb', Muhammad Ayaz', Farhat Ullah ${ }^{1}$ and Abu Nasar Siddique ${ }^{2}$

\begin{abstract}
Background: Herbal medicines have long been used for various ailments in various societies and natural bioactive compounds are gaining more and more importance due to various factors. In this context, three plant species i.e., Eryngium caeruleum, Notholirion thomsonianum and Allium consanguineum have been aimed for the scientific verification of their purported traditional uses against various infectious diseases.

Methods: In this study, three plants were assayed for antibacterial and antifungal potentials. The antibacterial investigations were performed via well diffusion method and nutrient broth dilution method. The bacterial strains used in the study were Enterococcus faecalis, Proteus mirabilis, Escherichia coli, Salmonella typhi, Klebsiella pneumonia and Pseudomonas aeruginosa. The antifungal potential was investigated by dilution method of Muller-Hinton agar media of the plants' samples. The fungal strains used were Aspergillis fumigatus, Aspergillis flavus and Aspergillis niger. Ceftriaxone and nystatin were used as standard drugs in antibacterial and antifungal assays respectively.
\end{abstract}

Results: Different fractions from $N$. thomsonianum were tested against five bacterial strains while the samples from $A$. consanguineum and E. caeruleum were tested against six bacterial strains. All the samples exhibited prominent antibacterial activity against the tested strains. Overall, chloroform and ethyl acetate fractions were found most potent among the three plants' samples. $N$. thomsonianum excelled among the three plants in antibacterial activity. Similarly, in antifungal assay, N. thomsonianum exhibited strong antifungal activity against the fungal strains. The chloroform fraction displayed MFCs of $175.67 \pm 5.20^{* * *}, 29.33 \pm 5.48^{* * *}$ and $63.00 \pm 4.93^{* * *} \mu \mathrm{g} / \mathrm{ml}$ against Aspergillus fumigatus, Aspergillus flavus and Aspergillus niger respectively. The whole study demonstrates that all the three plant species were active against tested bacterial and fungal strains.

Conclusion: It can be concluded from our findings that N. thomsonianum, A. consanguineum and E. caeruleum have broad antibacterial and antifungal potentials. In all of the plants' samples, chloroform and ethyl acetate fractions were more active. Furthermore, being the potent samples, the chloroform and ethyl acetate fractions of these plants can be subjected to column chromatography for the isolation of more effective antimicrobial drugs.

Keywords: Notholirion thomsonianum, Allium consanguineum, Eryngium caeruleum, Antibacterial, Antifungal, ZOI, MIC, MFC

\footnotetext{
* Correspondence: sadiquom@yahoo.com

'Department of Pharmacy, University of Malakand, Chakdara, 18000 Dir (L),

KPK, Pakistan

Full list of author information is available at the end of the article
} 


\section{Background}

Herbal therapies have long history for their use in various ailments. Being comparatively harmless, the natural products have attracted the focus of innovative researchers in the treatment of various challenging diseases [1, 2]. Microbial infections including tuberculosis, urinary tract infections (UTI's), meningitis, dermatitis, otitis media caused by bacterial and fungal strains are among the challenging diseases for the scientific community [3-5]. The morbidity rate of diseases originated from bacteria and fungi is surpassing various other diseases [6, 7]. The use of antibacterial and antifungal drugs is a main approach among the therapeutic options to treat bacterial and fungal infections [8]. But still there are numerous factors which minimize the therapeutic outcome of the antibiotic therapy. Beside various factors, the microbial resistance has prominently diminished the efficacy of antibiotics and the microbial resistance is the major cause of failure to treat bacterial and fungal infections $[9,10]$. Moreover, adverse drug reactions and hypersensitivity reactions associated with the use of various synthetic antimicrobial agents have decreased the interest of scientists to synthesize novel drugs having antimicrobial potentials. Therefore, the attention of researchers is mainly focused towards the natural compounds isolated from various plants [11-16]. Plants have been reported to possess antimicrobial potentials due to the presence of various secondary metabolites $[17,18]$. The alkaloids and flavonoids have been reported to possess strong antimicrobial potentials against bacteria and fungi $[19,20]$. Flavonoids like robinetin, myricetin, apigenin, rutin, Kuwanon $C$, mulberrofuran G, albanol B, kenusanone A and sophoraflavanone $\mathrm{G}$ isolated from various plants like Morus alba L., Morus mongolica Schneider, Broussnetia papyrifera (L.) Vent, Sophora flavescens Ait and Echinosophora koreensis Nakai have been reported to possess strong antibacterial potentials [19]. Similarly, alkaloids like sampangine and azafluorenone isolated from Cananga odorata and Mitrephora diversifolia respectively have also been reported to possess strong antifungal activities [21-24]. Varieties of plants belonging to different families have been scientifically verified for antimicrobial potentials. The scientific verification of a specific plant for the specific pharmacological activity is based on the traditional knowledge of species from the plant family. A specific biological potential of specific plant can be heralded by the ethnobotany and ethnomedicine [25].

Eryngium caeruleum belongs to the family Apiaceae. Several species of this genus have been reported to possess antimicrobial activities [26]. Similarly, Notholirion thomsonianum belongs to the family Liliaceae. This plant has been used ethnomedicinally for the treatment of various infectious diseases especially intestinal [27]. Likewise, Allium consanguineum belongs to the family Amaryllidaceae. A wide variety of species of Allium genus have been reported to possess notable antimicrobial properties in which the onion and garlic are the prominent candidates [28-30]. The selection of these plants species for antimicrobial studies was made on the basis of their traditional uses as well as their genera and family background. Similarly, the rhizomes of $N$. thomsonianum and $A$. consanguineum were exploited for extraction due to ethnomedicinal use of rhizome. Secondly, the rhizomes and underground part of multiple plants of the families of these plants have been reported to be rich sources of numerous bioactive compounds i.e., Allium sativum and Allium cepa [31]. Likewise, the aerial parts of several species of Eryngium are reportedly good source of secondary metabolites and possess pharmacological potentials [32]. Therefore, the aerial parts of E. caeruleum were employed for extraction. Therefore, the current study was aimed to evaluate the antibacterial and antifungal potentials of Eryngium caeruleum, Notholirion thomsonianum and Allium consanguineum and scientifically validate its folkloric uses.

\section{Methods \\ Plant collection and extraction}

The plants used in this research, i.e. E. caeruleum, N. thomsonianum and $A$. consanguineum were collected from Malakand division, KPK, Pakistan, located at Latitude: $34.5030^{\circ} \mathrm{N}$ and Longitude: $71.9046^{\circ} \mathrm{E}$ and authenticated by Dr. Nasrullah at Department of Botany, University of Malakand, Pakistan. Sample of each plant is submitted/ stored in the herbarium of University of Malakand, Pakistan. The voucher numbers given by the herbarium officials are H.UOM.BG.109 (E. caeruleum) H.UOM.BG.106 (N. thomsonianum) and H.UOM.BG.158 (A. consanguineum). The rhizomes of the $N$. thomsonianum and $A$. consanguineum were isolated from the plants weighing approximately $3 \mathrm{~kg}$ each, divided into small pieces and shade dried for 2 to 3 weeks. Likewise, the aerial parts of $E$. caeruleum were collected and dried in the shade. After drying, each plant materials were cut using a cutter mill into a powder and macerated in $80 \%$ methanol for 2 weeks. After individual soaking these plant samples were filtered using Whattman filter paper (Whatman no. 1). The filtrates were evaporated using rotary evaporator (Heidolph Laborota 4000 , Schwabach, Germany) at $40^{\circ} \mathrm{C}$ under reduced pressure $[33,34]$. Semi solid masses of methanolic extracts of $E$. caeruleum, $N$. thomsonianum and $A$. consanguineum were obtained weighing approximately $400 \mathrm{~g}$ each.

\section{Fractionation}

The successive solvent-solvent extraction procedure was followed for the fractionation of these plants samples. The crude methanolic extracts of E. caeruleum, $N$. thomsonianum and A. consanguineum (300 g each) were suspended separately in $500 \mathrm{ml}$ of distilled water in 
separating funnels and diluted with $500 \mathrm{ml}$ of $n$-hexane. After vigorously shaking, all the three extracts were allowed to separate into two distinct layers. The upper $n$-hexane layer was collected and the same procedure was repeated until colorless $n$-hexane layer was obtained. After the collection of $n$-hexane fraction of each plant, it was fractionated with other solvents with increasing polarity i.e., chloroform, ethyl acetate and at last the aqueous fraction was obtained. The weights obtained for $n$-hexane, chloroform, ethyl acetate and aqueous fractions of E. caeruleum were $62 \mathrm{~g}(20.66 \%), 37 \mathrm{~g}$ (12.33\%), $59 \mathrm{~g}(19.66 \%)$ and $110 \mathrm{~g}(36.66 \%)$ respectively. Similarly, the weights obtained for $n$-hexane, chloroform, ethyl acetate and aqueous fractions of $N$. thomsonianum were $69 \mathrm{~g}(23 \%), 45 \mathrm{~g}(15 \%), 51 \mathrm{~g}(17 \%)$ and $81 \mathrm{~g}(27 \%)$ respectively. Likewise, the weights obtained for $n$-hexane, chloroform, ethyl acetate and aqueous fractions of $A$. consanguineum were $45 \mathrm{~g}$ (15\%), $37 \mathrm{~g}$ (12.33\%), $64 \mathrm{~g}$ (21.33\%) and $96 \mathrm{~g}(32 \%)$ respectively [35-38].

\section{Bacterial and fungal strains}

Antibacterial potential of plants' samples were investigated against Enterococcus faecalis (stools), Esherichia coli (UTI), Proteus mirabilis (UTI), Pseudomonas aeruginosa (Burn patient skin), Klebsiella pneumoniae (UTI), Salmonella typhi (Stools). All bacterial and fungal strains were kindly donated by Department of Microbiology, Quaid-e-Azam University, Islamabad, Pakistan. These were identified by various biochemical tests and were kept at $4^{\circ} \mathrm{C}$ in agar slants in freeze-dried condition until later use [39]. The fungicidal activity was determined against Aspergillus fumigates (patient's sputum), Aspergillus niger (grapes) and Aspergillus flavus (soil) were used.

\section{Preparation and standardization of bacterial and fungal strains}

The cultures of bacterial strains were prepared by incubating at $37^{\circ} \mathrm{C}$ for $24 \mathrm{~h}$. The suspensions of bacterial strains with cell density of $1 \times 10^{8} \mathrm{CFU} / \mathrm{ml}$ were prepare by comparing with McFarland standard No 2 and was later on diluted to a cell density of $1 \times 10^{6} \mathrm{CFU} / \mathrm{ml}$ through double beam UV-visible spectrophotometer (Thermo electron corporation USA) at $625 \mathrm{~nm}$. Fungal strains were grown at $25^{\circ} \mathrm{C}$ and suspensions corresponding to $2.5 \times 104$ cells $\mathrm{ml}-1$ were prepared by dilution in normal saline. Standardization of fungal strains were done using microscopic enumeration with a cell-counting hematocytometer and optical density method as previously reported [40]. Fungal strains were identified according to principles and procedures of clinical laboratory standard institute (CLSI) for the detection of fungi in clinical specimens [41].

\section{Antibacterial assay}

The well-diffusion method was used for the evaluation of antibacterial activity of various samples of the three plants [42, 43]. Nutrient agar plates were prepared, properly labeled and inoculated with the test organisms under laminar flow hood with aseptic conditions. Wells having diameter of $5 \mathrm{~mm}$ were made in the agar plate using a sterilized cork borer. Samples of various extracts of plants were prepared having concentration of $10 \mathrm{mg} /$ $\mathrm{ml}$. Samples of each plant having volume of $100 \mu \mathrm{l}$ were transferred into the respective wells of petri dishes using micropipette. In each petri plate, four wells at the sides and one well in the center were made.

In the center one, ceftriaxone $(1 \mathrm{mg} / \mathrm{ml})$ was added which served as positive control while in the rest of wells, the plant samples were added. The petri dishes were kept at $37^{\circ} \mathrm{C}$ in BOD incubator for $24 \mathrm{~h}$. After incubation, the zone of inhibition of each sample was measured in $\mathrm{mm}$. All the samples were run in triplicate and the data obtained was expressed as mean \pm SEM.

\section{Determination of MICs}

For the determination of minimum inhibitory concentration (MICs), the broth dilution method was employed. Briefly, stock solution having the concentration of $50 \mathrm{mg} / \mathrm{ml}$ was prepared in sterile distilled water. Various dilutions were prepared from the stock solution ranging from 0.125 to $10 \mathrm{mg} / \mathrm{ml}$. Nutrient broth media was prepared in sterile water and sterilized in autoclave. The media prepared was inoculated with various strains in separate conical flasks. A few $\mathrm{ml}$ of inoculated media was transferred aseptically into properly labeled test tubes under laminar flow hood and the test samples were added to them. The test tubes were incubated at $37^{\circ} \mathrm{C}$ for $24 \mathrm{~h}$. After incubation, the test tubes were observed for turbidity which is directly related to the growth of bacterial strains. Similarly, the MICs of each plant's sample were recorded as the maximum concentration at which no turbidity was observed [44-46].

\section{Determination of MFCs}

Antifungal activity was carried out for the plants' samples against $A$. fumigatus, $A$. niger and $A$. flavus. The plants' samples of various dilutions $(62.5 \mu \mathrm{g} / \mathrm{ml}$ to $10 \mathrm{mg} / \mathrm{ml}$ ) were prepared in DMSO. Fungal media, i.e. muller hinton agar media was prepared in sterile water and autoclaved. A few $\mathrm{ml}$ of the prepared media was transferred to the labeled test tubes and $1 \mathrm{ml}$ of plants' sample was added to each of them. The test tubes were inoculated with test strains and incubated in BOD incubator at $25^{\circ} \mathrm{C}$ for 8 days. After incubation, the test tubes were observed for fungal growth. The minimum fungicidal concentrations (MFCs) were recorded as the maximum concentration of the sample at which no 
fungal growth was observed in test tubes. All the procedure was performed in triplicate and the nystatin was employed as positive control $[47,48]$.

\section{Statistical analysis}

Two-way ANOVA followed by Bonferroni's multiple comparison test was applied for the comparison of positive control with the test groups. $P$ values less than or equal to 0.05 were considered statistically significant. The standard error of mean (SEM) were calculated at 95\% confidence intervals.

\section{Results}

\section{Antibacterial assays}

\section{Zone of inhibitions (ZOIs) determination}

The well diffusion method was used for the three plants against various bacterial strains. The crude extracts and sub-fractions were analyzed for their antibacterial effect by the determination of their inhibitory zones against each strain. Among the three plants, N. thomsonianum exhibited the highest inhibitory zones against the tested strains. The Nt.Cf exhibited $31.67 \pm 0.67,29.33 \pm 0.88$, $26.33 \pm 0.33,25.67 \pm 0.67$ and $29.33 \pm 0.88 \mathrm{~mm}$ zone of inhibitions (ZOI) against P. mirabilis, E. coli, S. typhi, K. pneumonia and $P$. aeruginosa respectively as shown in Table 1. The antibacterial effect of Nt.Cf was almost comparable to the effects of the positive control. In the remaining fractions of $N$. thomsonianum, Nt.EtAc and
Nt.Cr also demonstrated notable antibacterial potentials. The least activity is attributed to the Nt.Hex fraction.

The $A$. consanguineum also showed notable inhibitory zones against the tested strains. Among different samples of A. consanguineum, the Ac.EtAc and Ac.Cf displayed considerable ZOIs in comparision to the positive control. The Ac.EtAc demonstrated $15.50 \pm 0.76,12.66 \pm$ $0.88,6.83 \pm 0.92,19.16 \pm 0.44,20.83 \pm 0.44$ and $10.33 \pm$ $0.60 \mathrm{~mm}$ ZOIs against E. faecalis, P. mirabilis, E. coli, S. typhi, $K$. pneumonia and $P$. aeruginosa respectively (Table 1). Moreover, almost all the solvent fractions of $E$. caeruleum were active against all the strains but the antibacterial effect of this plant was relatively low compared to the other two plants. However, the chloroform and ethyl acetate fractions were still observed to have dominant antibacterial activity amongst other fractions of E. caeruleum.

\section{Minimum inhibitory concentrations (MICs) determination}

The minimum concentration of each sample of $N$. thomsonianum, $A$. consanguineum and $E$. caeruleum was evaluated using agar dilution method in which all the samples exhibited specific MIC values. The MIC values of the three plants are summarized in Table 2. Among the test samples, the chloroform fractions (Nt.Cf, Ac.Cf, Ec.Cf) showed the least MIC values against all the test strains. It means that the chloroform fractions of the three plants were the most active among the rest of the

Table 1 Zone of inhibitions of the solvents fractions in millimeter from three plants against various bacterial strains

\begin{tabular}{|c|c|c|c|c|c|c|c|}
\hline Plant & Samples & $\begin{array}{l}\text { Enterococcus } \\
\text { faecalis }\end{array}$ & $\begin{array}{l}\text { Proteus } \\
\text { mirabilis }\end{array}$ & $\begin{array}{l}\text { Escherichia } \\
\text { coli }\end{array}$ & $\begin{array}{l}\text { Salmonella } \\
\text { typhi }\end{array}$ & $\begin{array}{l}\text { Klebsiella } \\
\text { pneumonia }\end{array}$ & $\begin{array}{l}\text { Pseudomonas } \\
\text { aeruginosa }\end{array}$ \\
\hline \multirow[t]{6}{*}{ Eryngium caeruleum } & Ec.Cr & $11.16 \pm 0.60^{* * *}$ & $12.16 \pm 0.44^{* * *}$ & $7.83 \pm 0.72^{* * *}$ & $17.66 \pm 0.88^{* * *}$ & $15.83 \pm 1.01^{* * *}$ & $7.16 \pm 0.60^{* * *}$ \\
\hline & Ec.Hex & $11.66 \pm 0.88^{* * *}$ & $13.16 \pm 0.44^{* * *}$ & $6.83 \pm 1.01^{* * *}$ & $16.16 \pm 0.72^{* * *}$ & $12.83 \pm 0.92^{* * *}$ & $9.16 \pm 0.44^{* * *}$ \\
\hline & Ec.Cf & $14.16 \pm 0.72^{* *}$ & $17.33 \pm 0.44^{* * *}$ & $7.16 \pm 0.60^{* * *}$ & $15.16 \pm 0.44^{* * *}$ & $18.33 \pm 0.92^{* * *}$ & $20.16 \pm 0.44^{* * *}$ \\
\hline & Ec.EtAc & $16.16 \pm 0.72^{*}$ & $13.16 \pm 0.60^{* * *}$ & $7.66 \pm 0.88^{* * *}$ & $18.33 \pm 0.72^{* * *}$ & $20.66 \pm 0.88^{* * *}$ & $11.50 \pm 1.04^{* * *}$ \\
\hline & Ec.Aq & $13.50 \pm 0.86^{* *}$ & $12.83 \pm 0.92^{* * *}$ & $8.16 \pm 0.72^{* * *}$ & $13.16 \pm 0.44^{* * *}$ & $17.16 \pm 0.44^{* * *}$ & $12.83 \pm 0.92^{* * *}$ \\
\hline & Ceftr & $21.30 \pm 0.41$ & $39.67 \pm 0.33$ & $32.67 \pm 0.88$ & $36.67 \pm 0.67$ & $32.67 \pm 0.33$ & $39.33 \pm 0.33$ \\
\hline \multirow[t]{6}{*}{ Notholirion thomsonianum } & Nt.Cr & $\mathrm{Nd}$ & $20.33 \pm 0.33^{* * *}$ & $29.00 \pm 0.58^{*}$ & $25.33 \pm 0.33^{* * *}$ & $16.67 \pm 0.33^{* * *}$ & $22.00 \pm 0.58^{* * *}$ \\
\hline & Nt.Hex & $\mathrm{Nd}$ & $17.33 \pm 0.33^{* * *}$ & $17.67 \pm 0.67^{* * *}$ & - & $16.33 \pm 0.33^{* * *}$ & $07.00 \pm 0.58^{* * *}$ \\
\hline & Nt.Cf & $\mathrm{Nd}$ & $31.67 \pm 0.67^{* * *}$ & $29.33 \pm 0.88^{*}$ & $26.33 \pm 0.33^{* * *}$ & $25.67 \pm 0.67^{* * *}$ & $29.33 \pm 0.88^{* * *}$ \\
\hline & Nt.EtAc & $\mathrm{Nd}$ & $26.67 \pm 0.33^{* * *}$ & $21.00 \pm 0.58^{* * *}$ & $21.67 \pm 0.67^{* * *}$ & $14.33 \pm 0.88^{* * *}$ & $09.33 \pm 0.88^{* * *}$ \\
\hline & Nt.Aq & $\mathrm{Nd}$ & $29.33 \pm 0.33^{* * *}$ & - & $16.67 \pm 0.33^{* * *}$ & $27.67 \pm 0.67^{* *}$ & $26.67 \pm 0.33^{* * *}$ \\
\hline & Ceftr & $21.3 \pm 0.41$ & $39.67 \pm 0.33$ & $32.67 \pm 0.88$ & $36.67 \pm 0.67$ & $32.67 \pm 0.33$ & $39.33 \pm 0.33$ \\
\hline \multirow[t]{6}{*}{ Allium consanguineum } & Ac.Cr & $9.66 \pm 0.88^{* * *}$ & $13.33 \pm 1.20^{* * *}$ & $6.83 \pm 0.60^{* * *}$ & $19.33 \pm 0.88^{* * *}$ & $17.66 \pm 1.45^{* * *}$ & $6.33 \pm 0.88^{* * *}$ \\
\hline & Ac.Hex & $11.33 \pm 0.66^{* * *}$ & $12.66 \pm 0.88^{* * *}$ & $5.83 \pm 0.60^{* * *}$ & $16.30 \pm 0.88^{* * *}$ & $13.66 \pm 0.88^{* * *}$ & $8.83 \pm 0.92^{* * *}$ \\
\hline & Ac.Cf & $15.50 \pm 0.86^{*}$ & $16.16 \pm 0.72^{* * *}$ & $7.00 \pm 0.50^{* * *}$ & $14.50 \pm 0.86^{* * *}$ & $19.16 \pm 0.44^{* * *}$ & $21.36 \pm 0.57^{* * *}$ \\
\hline & Ac.EtAc & $15.50 \pm 0.76^{*}$ & $12.66 \pm 0.88^{* * *}$ & $6.83 \pm 0.92^{* * *}$ & $19.16 \pm 0.44^{* * *}$ & $20.83 \pm 0.44^{* * *}$ & $10.33 \pm 0.60^{* * *}$ \\
\hline & Ac.Aq & $14.50 \pm 0.76^{* *}$ & $13.50 \pm 1.04^{* * *}$ & $7.10 \pm 0.58^{* * *}$ & $12.50 \pm 0.28^{* * *}$ & $16.33 \pm 0.88^{* * *}$ & $9.83 \pm 0.44^{* * *}$ \\
\hline & Ceftr & $21.3 \pm 0.41$ & $39.67 \pm 0.33$ & $32.67 \pm 0.88$ & $36.67 \pm 0.67$ & $32.67 \pm 0.33$ & $39.33 \pm 0.33$ \\
\hline
\end{tabular}


Table 2 Minimum inhibitory concentrations of the solvents fractions from three plants against various bacterial strains in $\mu \mathrm{g} / \mathrm{ml}$

\begin{tabular}{|c|c|c|c|c|c|c|c|}
\hline Plant & Samples & $\begin{array}{l}\text { Enterococcus } \\
\text { faecalis }\end{array}$ & $\begin{array}{l}\text { Proteu } \\
\text { mirabillis }\end{array}$ & $\begin{array}{l}\text { Escherichia } \\
\text { coli }\end{array}$ & $\begin{array}{l}\text { Salmonella } \\
\text { typhi }\end{array}$ & $\begin{array}{l}\text { Klebsiella } \\
\text { pneumonia }\end{array}$ & $\begin{array}{l}\text { Pseudomonas } \\
\text { aeruginosa }\end{array}$ \\
\hline \multirow[t]{6}{*}{ Eryngium caeruleum } & Ec.Cr & $309.43 \pm 2.08^{* * *}$ & $380.34 \pm 4.17^{* * *}$ & $326.33 \pm 7.12^{* * *}$ & $653.74 \pm 4.48^{* * *}$ & $774.65 \pm 3.28^{* * *}$ & $823.64 \pm 6.37^{* * *}$ \\
\hline & Ec.Hex & $386.70 \pm 3.20^{* * *}$ & $583.74 \pm 2.20^{* * *}$ & $316.64 \pm 0.31^{* * *}$ & $700.35 \pm 5.570^{* * *}$ & $614.64 \pm 5.575^{* * *}$ & $526.43 \pm 5.27^{* * *}$ \\
\hline & Ec.Cf & $420.45 \pm 4.21^{* * *}$ & $416.73 \pm 6.83^{* * *}$ & $540.40 \pm 3.30^{* * *}$ & $686.35 \pm 3.33^{* * *}$ & $273.74 \pm 4.371^{* * *}$ & $456.64 \pm 2.47^{* * *}$ \\
\hline & Ec.EtAc & $433.50 \pm 6.29^{* * *}$ & $470.32 \pm 4.25^{* * *}$ & $486.74 \pm 6.52^{* * *}$ & $556.32 \pm 3.66^{* * *}$ & $393.75 \pm 4.104^{* * *}$ & $373.29 \pm 6.371^{* * *}$ \\
\hline & Ec.Aq & $523.72 \pm 5.28^{* * *}$ & $703.64 \pm 4.46^{* * *}$ & $846.35 \pm 3.63^{* * *}$ & $983.64 \pm 6.440^{* * *}$ & $116.36 \pm 7.30^{* * *}$ & $873.36 \pm 4.371^{* * *}$ \\
\hline & Ceftr & $2.03 \pm 0.053$ & $3.867 \pm 0.384$ & $2.367 \pm 0.120$ & $1.67 \pm 0.167$ & $0.503 \pm 0.317$ & $1.67 \pm 0.120$ \\
\hline \multirow[t]{6}{*}{ Notholirion thomsonianum } & $\mathrm{Nt} . \mathrm{Cr}$ & nd & $87.67 \pm 1.20^{* * *}$ & $58.67 \pm 2.18^{* * *}$ & $179.67 \pm 1.76^{* * *}$ & $933.33 \pm 1.45^{* * *}$ & $501.33 \pm 1.85^{* * *}$ \\
\hline & Nt.Hex & nd & $176.67 \pm 2.02^{* * *}$ & $255.33 \pm 2.60^{* * *}$ & - & $1132.00 \pm 4.35^{* * *}$ & $913.67 \pm 3.48^{* * *}$ \\
\hline & Nt.Cf & nd & $39.67 \pm 4.05^{* * *}$ & $280.00 \pm 3.00^{* * *}$ & $47.33 \pm 3.52^{* * *}$ & $73.33 \pm 2.84^{* * *}$ & $63.33 \pm 2.84^{* * *}$ \\
\hline & Nt.EtAc & nd & $768.33 \pm 1.85^{* * *}$ & $404.67 \pm 2.72^{* * *}$ & $534.33 \pm 2.40^{* * *}$ & $504.00 \pm 3.51^{* * *}$ & $388.67 \pm 1.76^{* * *}$ \\
\hline & Nt.Aq & nd & $803.33 \pm 3.33^{* * *}$ & - & $723.33 \pm 3.93^{* * *}$ & $512.67 \pm 3.84^{* * *}$ & $633.67 \pm 3.71^{* * *}$ \\
\hline & Ceftr & $2.03 \pm 0.053$ & $3.867 \pm 0.384$ & $2.367 \pm 0.120$ & $1.67 \pm 0.167$ & $0.503 \pm 0.317$ & $1.67 \pm 0.120$ \\
\hline \multirow[t]{6}{*}{ Allium consanguineum } & Ac.Cr & $333.45 \pm 4.833^{* * *}$ & $666.86 \pm 6.66^{* * *}$ & $208.83 \pm 4.16^{* * *}$ & $583.54 \pm 2.20^{* * *}$ & $833.43 \pm 1.66^{* * *}$ & $666.29 \pm 7.66^{* * *}$ \\
\hline & Ac.Hex & $416.24 \pm 6.83^{* * *}$ & $416.22 \pm 8.38^{* * *}$ & $333.73 \pm 8.33^{* * *}$ & $833.75 \pm 3.66^{* * *}$ & $500.00 \pm 0.00^{* * *}$ & $166.45 \pm 4.16^{* * *}$ \\
\hline & Ac.Cf & $104.76 \pm 6.211^{* * *}$ & $208.64 \pm 4.86^{* * *}$ & $83.34 \pm 4.21^{* * *}$ & $416.65 \pm 4.83^{* * *}$ & $166.53 \pm 4.26^{* * *}$ & $208.65 \pm 4.76^{* * *}$ \\
\hline & Ac.EtAc & $208.64 \pm 3.48^{* * *}$ & $166.54 \pm 5.41^{* * *}$ & $416.65 \pm 5.83^{* * *}$ & $333.54 \pm 6.83^{* * *}$ & $208.36 \pm 3.41^{* * *}$ & $25.00 \pm 0.00^{* * *}$ \\
\hline & Ac.Aq & $761.64 \pm 3.89^{* * *}$ & $684.53 \pm 7.66^{* * *}$ & $1333.54 \pm 4.83^{* * *}$ & $833.63 \pm 5.32^{* * *}$ & $833.64 \pm 3.66^{* * *}$ & $666.53 \pm 1.66^{* * *}$ \\
\hline & Ceftr & $203 \pm 0.053$ & $3.867 \pm 0.384$ & $2.367 \pm 0.120$ & $1.67 \pm 0.167$ & $0.503 \pm 0.317$ & $1.67 \pm 0.120$ \\
\hline
\end{tabular}

Values significantly different as compared to standard drug i.e. ${ }^{* * *}: p<0.001,{ }^{* *}: p<0.01$ and ${ }^{*}: p<0.05$

samples. The chloroform fraction of $N$. thomsonianum exhibited MIC values of $39.67 \pm 4.05,280.00 \pm 3.00$, $47.33 \pm 3.52,73.33 \pm 2.84$ and $63.33 \pm 2.84 \mu \mathrm{g} / \mathrm{ml}$ against P. mirabilis, E. coli, S. typhi, K. pneumonia and P. aeruginosa respectively. The chloroform fraction of $A$. consanguneum was observed with $104.76 \pm 6.21,208.64 \pm$ $4.86, \quad 83.34 \pm 4.21, \quad 416.65 \pm 4.83, \quad 166.53 \pm 4.26$ and $208.65 \pm 4.76 \mu \mathrm{g} / \mathrm{ml}$ against E. faecalis, P. mirabilis, E. coli, S. typhi, K. pneumonia and $P$. aeruginosa respectively. As obvious from our results in Tables 1 (ZOIs) and Table 2 (MICs) that E. caeruleum is comparatively low potent plant in antibacterial activity. However, among all the solvent fractions of E. caeruleum, chloroform and ethyl acetate fractions were observed with minimum inhibitory zones confirming the antibacterial possibility of this plant.

\section{Minimum fungicidal concentrations (MFCs)}

The antifungal effect of each sample was studied and the minimum fungicidal concentration was determined which revealed the least MFC values (high potential) of $N$. thomsonianum. Among the different fractions of $N$. thomsonianum, Nt.Cf exhibited the highest antifungal potential with MFC values of $175.67 \pm 5.20,29.33 \pm 5.48$ and $63.00 \pm 4.93 \mu \mathrm{g} / \mathrm{ml}$ against $A$. fumigatus, $A$. flavus and $A$. niger respectively as shown in Table 3 . All the samples of the three plants were found active against all the three fungal strains. Among the samples of $A$. consanguneum, chloroform and $n$-hexane fractions were found to be most active exhibiting overwhelming MFC values compared to other fractions. Similarly, the $E$. caeruleum was also found quite active against all the three fungal strains. The most active fraction of this plant was found to be Ec.Cf, which exhibited MFC values of $350.23 \pm 2.28, \quad 233.45 \pm 6.44$ and $250.64 \pm$ $4.76 \mu \mathrm{g} / \mathrm{ml}$ against $A$. fumigatus, A. flavus and A. niger respectively.

\section{Discussion}

Microbes are considered as the mainstay and origin of multiple diseases. Microbial infiltration into the body tissues and blood lead to various diseases some of which are difficult to treat and extremely lethal $[49,50]$. The etiology of various humans' infections may be related to bacteria, virus, fungi and protozoa. The bacterial infections like upper respiratory tract infection, lower respiratory tract infection, tuberculosis, pneumonia, bacillary dysentery etc. are getting more and more attention due to the increasing morbidity and mortality due to these infections [51, 52]. Similarly, most of the fungi have the ability to cause infection without getting entered into the blood stream or mucosa. Such type of fungal infections involve disruption of dermal layer and are contagious [53]. Moreover, the fungi may cause a lot of systemic infections as well [54]. To avoid various health complications, a wide variety of antimicrobial drugs are 
Table 3 Minimum fungicidal concentrations of the solvents fractions from three plants expressed as $\mu \mathrm{g} / \mathrm{ml}$

\begin{tabular}{lllllllr}
\hline Plant & $\begin{array}{l}\text { Fungal } \\
\text { strains }\end{array}$ & $\begin{array}{l}\text { Methanolic } \\
\text { extract }\end{array}$ & $\begin{array}{l}\text { n-Hexane } \\
\text { fraction }\end{array}$ & $\begin{array}{l}\text { Chloroform } \\
\text { fraction }\end{array}$ & $\begin{array}{l}\text { Ethylacetate } \\
\text { fraction }\end{array}$ & \multicolumn{1}{l}{$\begin{array}{l}\text { Aqueous } \\
\text { fraction }\end{array}$} & $\begin{array}{l}\text { Nystatin } \\
\text { Eryngium caeruleum }\end{array}$ \\
& 1 & $321.43 \pm 2.43^{* * *}$ & $433.33 \pm 4.33^{* * *}$ & $350.23 \pm 2.28^{* * * *}$ & $450.75 \pm 3.76^{* * *}$ & $616.25 \pm 2.60^{* * *}$ & $13.67 \pm 3.75$ \\
& 2 & $416.76 \pm 5.44^{* * *}$ & $333.96 \pm 2.60^{* * *}$ & $233.45 \pm 6.44^{* * *}$ & $450.43 \pm 5.57^{* * *}$ & $516.63 \pm 5.72^{* * *}$ & $9.33 \pm 2.60$ \\
& 3 & $333.92 \pm 3.88^{* * *}$ & $366.73 \pm 5.92^{* * *}$ & $250.64 \pm 4.76^{* * *}$ & $450.75 \pm 2.86^{* * *}$ & $616.75 \pm 3.88^{* * *}$ & $31.67 \pm 5.78$ \\
Notholirion thomsonianum & 1 & $254.67 \pm 2.72^{* * *}$ & $412.67 \pm 4.33^{* * *}$ & $175.67 \pm 5.20^{* * *}$ & $225.33 \pm 3.93^{* * *}$ & $301.67 \pm 4.40^{* * *}$ & $13.67 \pm 3.75$ \\
& 2 & $73.67 \pm 4.40^{* * *}$ & $585.33 \pm 3.93^{* * *}$ & $29.33 \pm 5.48^{* * *}$ & $213.67 \pm 4.25^{* * *}$ & $514.67 \pm 4.33^{* * *}$ & $9.33 \pm 2.60$ \\
& 3 & $116.67 \pm 3.84^{* * *}$ & $232.67 \pm 4.40^{* * *}$ & $63.00 \pm 4.93^{* * *}$ & $309.33 \pm 5.48^{* * *}$ & $382.67 \pm 4.40^{* * *}$ & $31.67 \pm 5.78$ \\
Allium consanguineum & 1 & $391.52 \pm 1.90^{* * *}$ & $364.56 \pm 2.19^{* * *}$ & $329.65 \pm 3.16^{* * *}$ & $372.43 \pm 3.57^{* * *}$ & $211.00 \pm 3.63^{* * *}$ & $13.67 \pm 3.75$ \\
& 2 & $713.76 \pm 2.91^{* * *}$ & $380.74 \pm 4.15^{* * *}$ & $790.00 \pm 3.17^{* * *}$ & $403.24 \pm 6.23^{* * *}$ & $513.74 \pm 2.24^{* * *}$ & $9.33 \pm 2.60$ \\
& 3 & $310.78 \pm 2.63^{* * *}$ & $326.83 \pm 8.12^{* * *}$ & $280.83 \pm 5.65^{* * *}$ & $502.65 \pm 3.15^{* * *}$ & $540.64 \pm 5.20^{* * *}$ & $31.67 \pm 5.78$ \\
\hline
\end{tabular}

Values significantly different as compared to standard drug i.e. ${ }^{* *}: p<0.001,{ }^{* *}: p<0.01$ and ${ }^{*}: p<0.05$

Key: 1 = Aspergillus fumigatus; 2 = Aspergillus flavus; $3=$ Aspergillus niger

used which avoid and alleviates the symptoms caused by microbes. The antimicrobial agents may interrupt the synthesis of metabolites which are necessary for the basic integrity of microbes including bacteria and fungi $[55,56]$. However, the main problem with the use of antimicrobial and other drugs is the hazardous and toxic effects associated with their use [57, 58]. Secondly, many microbes develop resistance to a specific group of drugs and they become less susceptible to that specific drug [55]. Fortunately, nature is kind enough to provide remedy for almost every disease [59]. The natural bioactive compounds being biodegradable and hydrolytic have been reported to possess comparatively low toxicity and high efficacy [60]. Investigators are in continuous search for the exploration of novel sources of more effective compounds for the treatment of challenging infectious diseases [61-63]. As previously reported, plants possess antibacterial secondary metabolites which are getting more and more importance due to their negligible toxicity and adverse effects [64, 65]. The aim of the current study is to have a step towards the achievement of novel natural antimicrobial agents. Results of the current study revealed that $N$. thomsonianum possess strong antibacterial and antifungal results. The MIC values of positive control and chloroform fraction were going considerably parallel i.e., if we cursorily observe the Table 2 , we can figure out the antibacterial potential in terms of MIC (39.67, 280.00, 47.33, 73.33, $63.33 \mu \mathrm{g} / \mathrm{ml}$ ) of chloroform fraction and that of positive control $(2.03,3.867$, $2.367,1.67,0.503,1.67 \mu \mathrm{g} / \mathrm{ml}$ ), which are relatively comparable. The MICs of chloroform fraction has been figured out to be smaller than $100 \mu \mathrm{g} / \mathrm{ml}$ against majority of the test strains, which reveals the significance of this fraction. This significance is in the terms of therapeutic applications against various bacterial infections. As variety of antimicrobial natural compounds and antibiotics have their MIC values lower than $100 \mu \mathrm{g} / \mathrm{ml}$, which are effective against various bacterial infections and are considered as therapeutically as well as statistically important data $[66,67]$.
Similarly, the antifungal activity of chloroform fraction is also dominant. It was also observed that the chloroform fraction was the most active one against bacterial and fungal strains. Against $A$. niger and A. flavus the chloroform fraction demonstrated MFC values of $63.00 \pm 4.93$ and $29.33 \pm 5.48 \mu \mathrm{g} / \mathrm{ml}$ respectively, which are less than $100 \mu \mathrm{g} /$ $\mathrm{ml}$, which can be considered to be significant in the context of therapy of various diseases [68]. The results obtained in the current study can be correlated with the previous publications. Other species of Allium also possess effective potential against microbes i.e., Allium sativum L. (garlic), Allium ampeloprasum L. (elephant garlic) and Allium cepa have been reported to possess strong antibacterial and antifungal activities [69]. Important antibacterial compound i.e., allicin has also been isolated from Allium sativum which has been reported to be active against various pathogenic bacterial strains [70]. In the same way, numerous species of Eryngium have been reported to possess antimicrobial potential. Eryngium palmatum one of medicinally important specie of Eryngium has been verified to be active against microbes [71]. Similarly, the Eryngium genus has also been reported to inhibit the methicillin-resistant Staphylococcus aureus strains significantly [72]. The results of the previous reports goes parallel with the results of our current investigational study which indicate that like other species of Allium and Eryngium the E. caeruleum, A. consanguineum and $N$. thomsonianum are also prominent candidates of these genera. The study reveals that among the three plants, $N$. thomsonianum was rich in antimicrobial agents and secondly it may also be implied that the chloroform fraction was rich in such secondary metabolites which confer antimicrobial potential to this plant.

\section{Conclusion}

Based on our current investigations it can be concluded that $N$. thomsonianum, A. consanguineum and E. caeruleum possess considerably sufficient antibacterial and antifungal potentials. It may also be concluded that 
antimicrobial potential of various samples of these plants might be due to wide variety of compounds present in these plants. Moreover, we observed that specifically the chloroform and upto some extent the ethyl acetate fractions of these plant contain considerably high activity. These two fractions (in each plant) are potent targets to be subjected to bio-guided isolation and exploration of novel natural antimicrobials.

\begin{abstract}
Abbreviations
Ac.Aq: Aqueous fraction of $A$. consanguineum; Ac.Cf: Chloroform fraction of $A$. consanguineum; Ac.Cr: Methanolic extract of A. consanguineum; Ac.EtAc: Ethyl acetate fraction of $A$. consanguineum; Ac. Hex: n-Hexane fraction of $A$. consanguineum; CLSI: Clinical laboratory standard institute; DMSO: Dimethyl sulfoxide; Ec.Aq: Aqueous fraction of E. caeruleum; Ec.Cf: Chloroform fraction of E. caeruleum; Ec.Cr: Methanolic extract of E. caeruleum; Ec.EtAc: Ethyl acetate fraction of E. caeruleum; Ec.Hex: n-Hexane fraction of E. caeruleum; MFC: Minimum fungicidal concentration; MIC: Minimum inhibitory concentration; Nt.Aq: Aqueous fraction of N. thomsonianum; Nt.Cf: Chloroform fraction of N. thomsonianum; Nt.Cr: Methanolic extract of N. thomsonianum; Nt.EtAc: Ethyl acetate fraction of N. thomsonianum: Nt.Hex: $n$-Hexane fraction of $N$. thomsonianum; UTI: Urinary tract infection; ZOI: Zone of inhibition
\end{abstract}

\section{Acknowledgements}

The authors sincerely thank to Dr. Nasrullah, plant taxonomist, Department of Botany University of Malakand, Pakistan for the identification of the plants. The authors also want to thank University of Malakand for providing laboratory facilities to conduct experiments.

\section{Funding}

This research received no specific grant from any funding agency in the public, commercial, or not-for-profit sectors.

\section{Availability of data and materials}

The data supporting our results is present within the manuscript.

\section{Authors' contributions}

Collection and fractionation of Eryngium caeruleum, Notholirion thomsonianum and Allium consanguineum was done by SA, RA and FA respectively. SA, AZ and MA helped in antibacterial and antifungal activities. FU and ANS contributed in idea of work and helped in microbial assays. AS supervised the overall research work and drafted the manuscript for publication. All authors read and approved the final manuscript.

\section{Competing interests}

The authors declare that they have no competing interest.

\section{Consent for publication}

Not applicable for this submission.

\section{Ethics approval and consent to participate}

Not applicable for this submission.

\section{Author details}

'Department of Pharmacy, University of Malakand, Chakdara, 18000 Dir (L), KPK, Pakistan. ${ }^{2}$ Department of Biotechnology, Bacha Khan University, Charsadda 24420, KPK, Pakistan.

Received: 3 February 2016 Accepted: 17 November 2016 Published online: 24 November 2016

\section{References}

1. Tripathi P, Dubey N. Exploitation of natural products as an alternative strategy to control postharvest fungal rotting of fruit and vegetables. Postharvest Biol Technol. 2004;32(3):235-45.

2. Ullah I, Subhan F, Ayaz M, Shah R, Ali G, Haq IU, Ullah S. Anti-emetic mechanisms of zingiber officinale against cisplatin induced emesis in the pigeon; behavioral and neurochemical correlates. BMC Complement Altern Med. 2015;15(1):34.

3. Puopolo KM. Bacterial and fungal infections. In: Cloherty JP, Eichenwald, Stark AR, editors. Manual of neonatal care. 5th ed. Philadelphia: Lippincott Williams \& Wilkins; 2004. p. 287-97.

4. Ullah F, Malik SA, Ahmed J, Ullah F, Shah SM, Ayaz M, Hussain S, Khatoon L. Investigation of the Genetic Basis of Tetracycline Resistance in Staphylococcus aureus from Pakistan. Trop J Pharm Res. 2012;11(6):925-31.

5. Khan SU, Khan A-U, Shah SM, Hussain S, Ayaz M, Ayaz S. Heavy metals content, phytochemical composition, antimicrobial and insecticidal evaluation of Elaeagnus angustifolia. Toxicol Ind Health. 2016;32(1):154-61.

6. Travers K, Michael B. Morbidity of infections caused by antimicrobialresistant bacteria. Clin Infect Dis. 2002;34(Supplement 3):S131-4.

7. Pagano L, Caira M, Picardi M, Candoni A, Melillo L, Fianchi L, Offidani M, Nosari A. Invasive aspergillosis in patients with acute leukemia: update on morbidity and mortality_SEIFEM-C Report. Clin Infect Dis. 2007;44(11):1524-5.

8. Stolz D, Christ-Crain M, Bingisser R, Leuppi J, Miedinger D, Muller C, Huber P, Muller B, Tamm M. Antibiotic treatment of exacerbations of COPD: a randomized, controlled trial comparing procalcitonin-guidance with standard therapy. Chest. 2007;131(1):9-19.

9. Goossens H, Ferech M, Vander Stichele R, Elseviers M, Group EP. Outpatient antibiotic use in Europe and association with resistance: a cross-national database study. Lancet. 2005;365(9459):579-87.

10. Shah SM, Ayaz M, Khan AU, Ullah F, Farhan, Shah AU, Iqbal H, Hussain S. 1,1-Diphenyl,2-picrylhydrazyl free radical scavenging, bactericidal, fungicidal and leishmanicidal properties of Teucrium stocksianum. Toxicol Ind Health. 2015;31(11):1037-43.

11. Wojcik M, Burzynska-Pedziwiatr I, Wozniak L. A review of natural and synthetic antioxidants important for health and longevity. Curr Med Chem. 2010;17(28):3262-88

12. Kamal Z, Ullah F, Ayaz M, Sadiq A, Ahmad S, Zeb A, Hussain A, Imran M. Anticholinesterase and antioxidant investigations of crude extracts, subsequent fractions, saponins and flavonoids of atriplex laciniata $L$.: potential effectiveness in Alzheimer's and other neurological disorders. Biol Res. 2015;48:21.

13. Shah S, Shah SMM, Ahmad Z, Yaseen M, Shah R, Sadiq A, Khan S, Khan B. Phytochemicals, in vitro antioxidant, total phenolic contents and phytotoxic activity of Cornus macrophylla Wall bark collected from the North-West of Pakistan. Pak J Pharm Sci. 2015;28(1):23-8.

14. Shah SM, Sadiq A, Ullah F. Antioxidant, total phenolic contents and antinociceptive potential of Teucrium stocksianum methanolic extract in different animal models. BMC Complement Altern Med. 2014;14(1):181.

15. Shah SMM, Sadiq A, Shah SMH, Khan S. Extraction of saponins and toxicological profile of Teucrium stocksianum boiss extracts collected from District Swat, Pakistan. Biol Res. 2014;47(1):65.

16. Shah SMM, Ullah F, Shah SMH, Zahoor M, Sadiq A. Analysis of chemical constituents and antinociceptive potential of essential oil of Teucrium Stocksianum bioss collected from the North West of Pakistan. BMC Complement Altern Med. 2012;12(1):244.

17. Ullah F, Ayaz M, Sadiq A, Hussain A, Ahmad S, Imran M, Zeb A. Phenolic, flavonoid contents, anticholinesterase and antioxidant evaluation of Iris germanica var; florentina. Nat Prod Res. 2016;30(12):1440-44.

18. Ayaz M, Junaid M, Ullah F, Sadiq A, Khan MA, Ahmad W, Shah MR, Imran M, Ahmad S. Comparative chemical profiling, cholinesterase inhibitions and anti-radicals properties of essential oils from Polygonum hydropiper L: A Preliminary anti-Alzheimer's study. Lipids Health Dis. 2015;14(1):141.

19. Cushnie T, Lamb AJ. Antimicrobial activity of flavonoids. Int J Antimicrob Agents. 2005;26(5):343-56

20. Faizi S, Khan RA, Azher S, Khan SA, Tauseef S, Ahmad A. New antimicrobial alkaloids from the roots of Polyalthia longifolia var. pendula. Planta Med. 2003;69(4):350-5.

21. Lago JHG, Chaves MH, Ayres MCC, Agripino DG, Young MCM. Evaluation of antifungal and DNA damaging activities of alkaloids from branches of Porcelia macrocarpa. Planta Medica. 2007;73(03):292-95.

22. Mink K, Bracher F. Hetero analogues of the antimicrobial alkaloids cleistopholine and sampangine. Arch Pharm. 2007;340(8):429-33.

23. Rao J, Giri G, Hanumaiah T, Rao K. Sampangine, a new alkaloid from Cananga odorata. J Nat Prod. 1986;49(2):346-7.

24. Mueller D, Davis RA, Duffy S, Avery VM, Camp D, Quinn RJ. Antimalarial activity of azafluorenone alkaloids from the Australian tree Mitrephora diversifolia. J Nat Prod. 2009;72(8):1538-40. 
25. Berlin B. Ethnobiological classification: Principles of categorization of plants and animals in traditional societies: Princeton: Princeton University Press; 1992.

26. Thiem B, Goslinska O, Kikowska M, Budzianowski J. Antimicrobial activity of three Eryngium L. species (Apiaceae). Herba Polonica. 2010;56(4):52-8.

27. Lone PA, Bhardwaj AK, Shah KW, Tabasum S. Ethnobotanical survey of some threatened medicinal plants of Kashmir Himalaya, India. J Med Plant Res. 2014;8(47):1362-73.

28. Benkeblia N. Antimicrobial activity of essential oil extracts of various onions (Allium cepa) and garlic (Allium sativum). LWT- Food Sci Technol. 2004;37(2):263-8.

29. Srinivasan D, Nathan S, Suresh T, Perumalsamy PL. Antimicrobial activity of certain Indian medicinal plants used in folkloric medicine. J

Ethnopharmacol. 2001;74(3):217-20.

30. Harris J, Cottrell S, Plummer S, Lloyd D. Antimicrobial properties of Allium sativum (garlic). Appl Microbiol Biotechnol. 2001;57(3):282-6.

31. Shams-Ghahfarokhi M, Shokoohamiri M-R, Amirrajab N, Moghadasi B, Ghajari A, Zeini F, Sadeghi G, Razzaghi-Abyaneh M. In vitro antifungal activities of Allium cepa, Allium sativum and ketoconazole against some pathogenic yeasts and dermatophytes. Fitoterapia. 2006;77(4):321-3.

32. Ebrahimzadeh MA, Nabavi SF, Nabavi SM. Antioxidant activity of leaves and inflorescence of Eryngium caucasicum Trautv at flowering stage. Pharmacog Res. 2009;1(6):435.

33. Zeb A, Sadiq A, Ullah F, Ahmad S, Ayaz M. Phytochemical and toxicological investigations of crude methanolic extracts, subsequent fractions and crude saponins of Isodon rugosus. Biol Res. 2014;47(1):57

34. Ahmad S, Ullah F, Ayaz M, Sadiq A, Zeb A, Imran M. Pharmacological evaluation of saponins, methanolic extract and subsequent fractions of Rumex hastatus D. Don against Monomorium pharaonis and Heterotermis indicola. Pharmacologyonline. 2015;1:13-8.

35. Zeb A, Sadiq A, Ullah F, Ahmad S, Ayaz M. Investigations of anticholinestrase and antioxidant potentials of methanolic extract, subsequent fractions, crude saponins and flavonoids isolated from Isodon rugosus. Biol Res. 2014;47(1):1-10

36. Shah S, Sadiq A, Gul F. Antibacterial potential of methanolic extracts and sub-fractions of Teucrium stocksianum Bioss collected from Malakand division, Pakistan. Pharmacologyonline. 2015;1:8-12.

37. Ayaz M, Junaid M, Ullah F, Sadiq A, Subhan F, Khan MA, Ahmad W, Ali G, Imran M, Ahmad S. Molecularly characterized solvent extracts and saponins from Polygonum hydropiper $\mathrm{L}$ show high anti-angiogenic, anti-tumor, brine shrimp and fibroblast NIH/3T3 cell line cytotoxicity. Front Pharmacol. 2016;7:74.

38. Zeb A, Ahmad S, Ullah F, Ayaz M, Sadiq A. Anti-nociceptive activity of ethnomedicinally important analgesic plant Isodon rugosus Wall. ex Benth: Mechanistic study and identifications of bioactive compounds. Front Pharmacol. 2016;7:200

39. Barrow Gl, Feltham RKA. In Cowan and Steel's Manual of the Identification of Medical Bacteria. Cambridge: Cambridge University Press; 1993. p. 50-9. 159-164.

40. Petrikkou E, Rodriguez-Tudela UL, Cuenca-Estrella M, Gómez A, Molleja A, Mellado E. Inoculum standardization for antifungal susceptibility testing of filamentous fungi pathogenic for humans. J Clin Microbiol. 2001;39(4):1345-7.

41. CLSI. Principles and procedures for the detection of fungi in clinical specimens-Direct examination and culture; Approved guidelines, CLSI document M54-A. Wayne: Clinical and Laboratory Standards Institute; 2012.

42. Imran M, Ullah F, Sadiq A, Ayaz M, Ahmad S, Kamal Z, Zeb A. Investigation of total phenolic contents, antibacterial, antifungal and anthelmintic potentials of crude methanolic extract, subsequent fractions and crude saponins of Nonea micrantha Boiss. \& Reut. Pharmacologyonline. 2014;3:26-31.

43. Zul K, Midrarullah, Sajjad A, Farhat U, Abdul S, Muhammad A, Anwar Z, Muhammad I. Ex-vivo antibacterial, phytotoxic and cytotoxic, potential in the crude natural phytoconstituents of Rumex hastatus D. Don. Pak J Bot. 2015;47(SI):293-9.

44. Usman H, Abdulrahman F, Ladan A. Phytochemical and Antimicrobial Evaluation of Tribulus terrestris L. (Zygophylaceae). Growing in Nigeria. Res J Biol Sci. 2007:3:244-7.

45. Ayaz M, Subhan F, Ahmed J, Khan AU, Ullah F, Ullah I, Ali G, Hussain S. Sertraline enhances the activity of antimicrobial agents against pathogens of clinical relevance. J Biol Res (Thessaloniki). 2015;22(1):4

46. Ayaz M, Subhan F, Ahmed J, Khan AU, Ullah F, Sadiq A, Syed N-I-H, Ullah I, Hussain S. Citalopram And Venlafaxine Differentially Augments Antimicrobial Properties Of Antibiotics. Acta Pol Pharm. 2015;72(6):1269-78.
47. Yotova I, TS I-I. In vitro Study of Antifungal Activity of Oregano (Origanum vulgare). Int J Curr Microbiol App Sci. 2015:4(3):321-6.

48. Chandrasekaran M, Venkatesalu V. Antibacterial and antifungal activity of Syzygium jambolanum seeds. J Ethnopharmacol. 2004;91(1):105-8.

49. Morens DM, Folkers GK, Fauci AS. The challenge of emerging and reemerging infectious diseases. Nature. 2004;430(6996):242-9.

50. Horner AA, Raz E. Do microbes influence the pathogenesis of allergic diseases? Building the case for Toll-like receptor ligands. Curr Opin Immunol. 2003;15(6):614-9.

51. Salyers AA, Whitt DD. Bacterial Pathogenesis: A Molecular Approach. Washington: American Society for Microbiology Press; 1994.

52. Verani J, McGee L, Schrag S: Division of Bacterial Diseases. National Center for Immunization and Respiratory Diseases, Centers for Disease Control and Prevention (CDC) 2010, 59:1-36

53. Denning DW, Hope WW. Therapy for fungal diseases: opportunities and priorities. Trends Microbiol. 2010;18(5):195-204.

54. Bhalaria M, Naik S, Misra A. Ethosomes: a novel delivery system for antifungal drugs in the treatment of topical fungal diseases. Indian J Exp Biol. 2009;47(5):368.

55. Tenover FC. Mechanisms of antimicrobial resistance in bacteria. Am J Med. 2006;119(6):S3-10

56. Ghannoum MA, Rice LB. Antifungal agents: mode of action, mechanisms of resistance, and correlation of these mechanisms with bacterial resistance. Clin Microbiol Rev. 1999;12(4):501-17.

57. Dancer SJ. How antibiotics can make us sick: the less obvious adverse effects of antimicrobial chemotherapy. Lancet Infect Dis. 2004;4(10):611-9.

58. Sadiq A, Mahmood F, Ullah F, Ayaz M, Ahmad S, Haq FU, Khan G, Jan MS. Synthesis, anticholinesterase and antioxidant potentials of ketoesters derivatives of succinimides: a possible role in the management of Alzheimer's. Chem Cent J. 2015;9(1):31.

59. Clark AM. Natural products as a resource for new drugs. Pharm Res. 1996;13(8):1133-41.

60. Park J, Ye M, Park K. Biodegradable polymers for microencapsulation of drugs. Molecules. 2005;10(1):146-61.

61. Ayaz M, Junaid M, Ahmed J, Ullah F, Sadiq A, Ahmad S, Imran M. Phenolic contents, antioxidant and anticholinesterase potentials of crude extract, subsequent fractions and crude saponins from Polygonum hydropiper $\mathrm{L}$. BMC Complement Altern Med. 2014;14(1):145.

62. Ayaz M, Junaid M, Subhan F, Ullah F, Sadiq A, Ahmad S, Imran M, Kamal Z, Hussain S, Shah SM. Heavy metals analysis, phytochemical, phytotoxic and anthelmintic investigations of crude methanolic extract, subsequent fractions and crude saponins from Polygonum hydropiper L. BMC Complement Altern Med. 2014;14(1):465.

63. Khan H, Khan MA, Abdullah. Antibacterial, antioxidant and cytotoxic studies of total saponin, alkaloid and sterols contents of decoction of Joshanda: identification of components through thin layer chromatography. Toxicol Ind Health. 2015;31(3):202-8.

64. Rai M, Carpinella M. Naturally occurring bioactive compounds. Amsterdam: Elsevier; 2006. p. 502.

65. Rates SMK. Plants as source of drugs. Toxicon. 2001;39(5):603-13.

66. Kohanski MA, DePristo MA, Collins JJ. Sublethal antibiotic treatment leads to multidrug resistance via radical-induced mutagenesis. Mol Cell. 2010;37(3):311-20.

67. Metzler CM, DeHaan RM. Susceptibility tests of anaerobic bacteria: statistical and clinical considerations. J Infect Dis. 1974;130(6):588-94.

68. Petranyi $G$, Meingassner JG, Mieth $H$. Antifungal activity of the allylamine derivative terbinafine in vitro. Antimicrob Agents Chemother. 1987;31(9):1365-8.

69. Hughes BG, Lawson LD. Antimicrobial effects of Allium sativum L. (garlic), Allium ampeloprasum L. (elephant garlic), and Allium cepa L. (onion), garlic compounds and commercial garlic supplement products. Phytother Res. 1991:5(4):154-8.

70. Cavallito $\mathrm{CJ}$, Bailey $\mathrm{JH}$. Allicin, the antibacterial principle of Allium sativum. I. Isolation, physical properties and antibacterial action. J Am Chem Soc. 1944;66(11):1950-1.

71. Marčetić MD, Petrović SD, Milenković MT, Niketić MS. Composition, antimicrobial and antioxidant activity of the extracts of Eryngium palmatum Pančić and Vis. (Apiaceae). Cent Eur J Biol. 2014;9(2):149-55.

72. Celik A, Aydınlık N, Arslan I. Phytochemical constituents and inhibitory activity towards methicillin-resistant Staphylococcus aureus strains of Eryngium species (Apiaceae). Chem Biodivers. 2011;8(3):454-9. 